\title{
Committee Nominates 2015-2016 Officers and Council Members
}

\begin{abstract}
he APSA Nominating Committee met at APSA on February 13, 2015, and has nominated the following candidates for APSA council positions. Each has agreed to serve if elected.

The candidates will be certified at the All-Member Business Meeting September 4, at 11:0o a.m., in San Francisco at the Annual Meeting. If there are no additional nominations from the membership for each office, the new members will be elected there; if there is a contest for any of the council positions, we will hold an all-member election in the autumn.

The nominating committee is Sheri Berman, Barnard College-Columbia University (Chair); James D. Fearon, Stanford University; Luis Fraga, University of Notre Dame; Kerry L. Haynie, Duke University; Sara Mitchell, University of Iowa; and Elizabeth Zechmeister, Vanderbilt University.
\end{abstract}

\section{PRESIDENT-ELECT \\ David A. Lake}

David A. Lake is the Jerri-Ann and Gary E. Jacobs Professor of Social Sciences and Distinguished Professor of Political Science at the University of California, San Diego. His research focuses broadly on international relations. $\mathrm{He}$ is the author of The Statebuilder's Dilemma: Legitimacy, Loyalty, and the Limits of External Intervention (Cornell 2016), Hierarchyin International

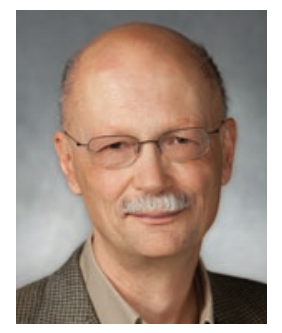

Relations (Cornell 2009), Entangling Relations: American Foreign Policy in Its Century (Princeton 1999), and Power, Protection and Free Trade: International Sources of US Commercial Strategy, 1887-1939 (Cornell 1988). He is also the coauthor of a comprehensive textbook, World Politics: Interests, Interactions, and Institutions (third edition, Norton 2016) and coeditor of nine volumes on international political economy, international security, and international organizations. His research articles have appeared in the American Political Science Review, the American Journal of Political Science, the European Journal of International Relations, InternationalOrganization, International Security, World Politics, and many other journals.

Lake received his $\mathrm{PhD}$ from Cornell University in 1984 and was on the faculty of the University of California, Los Angeles, 19831992. At UCSD, Lake has served as research director for international relations at the Institute on Global Conflict and Cooperation (1992-1996 and 2000-2001), chair of the political science department (2000-2004), associate dean of social sciences (2006-2015), and director of the Yankelovich Center for Social Science Research (2013-present). In the profession, he has served as coeditor of the journal International Organization (1997-2001), cofounder of the Political Science Network within the Social Science Research Network (2007), founding chair of the International Political Economy Society (2005-2012), and president of the International Studies Association (2010-2011). The recipient of UCSD Chancellor's Associates Awards for Excellence in Graduate Education (2005) and Excellence in Research in Humanities and Social Sciences (2013), he was elected to the American Academy of Arts and Sciences in 2006 and was a fellow at the Center for Advanced Study in the Behavioral Sciences in 2008-2009. He also received the Outstanding Mentor Award from the Society of Women in International Political Economy in 2012 and has helped train more than 60 PhD students at UCLA and UCSD.

Within the American Political Science Association, Lake was the founding chair of the Section on Political Economy (19901992), a member of the editorial search committee for Perspectives on Politics (2004), program cochair (2007), a member of the APSA Trust and Development Committee (20092011), a member of the Governing Council (2011-2013), chair of the Rules Committee (2012-2013), and chair of the ad hoc Committee on Governance Reform (2013-2016).

\section{VICE PRESIDENTS}

\section{Frank R. Baumgartner}

Frank R. Baumgartner holds the Richard J. Richardson Distinguished Professorship in Political Science at University of North Carolina-Chapel Hill. He received his PhD from the University of Michigan in 1986 after previously getting his BA and MA at that same institution. He taught for one year at the University of Iowa, then for 11 years at Texas A\&M University, and 10 years at Pennsylvania State University, and he has been at UNC-CH since 2009. He has had visiting appointments at Caltech, Sciences Po (Paris), and the European University Institute (Florence) as well as shorter visits at a number of universities in the US and western Europe. He served as department head at Penn State; is currently responsible for diversity efforts within the UNC department; has served in numerous capacities on various editorial boards including those of the Journal of Politics and American Journal of Political Science; and currently sits on several editorial boards, including Policy Studies Journal, Public Administration, and the Journal of European Public Policy. He has served on various leadership committees at the APSA, MPSA, and at NSF.

His work focuses on policy making processes, lobbying, agenda-setting, and framing in US and comparative perspective. This includes books such as Agendas and Instability in American Politics and The Politics of Information (with Bryan Jones), Lobbying and Policy Change, and The Decline of the Death Penalty and the Discovery of Innocence. He has edited several books as well, and published journal articles in many of the major US and European journals. He has been awarded the Aaron Wildavsky Enduring Contribution Award for a work of lasting influence in public policy; the Kammerer Award for the best book on US national policy; the Epstein Award for the best book on parties and organizations; and the Elsdersveld Career Achievement Award from the APSA Section on Political Organizations and Parties.

Statement of views: The APSA plays an important role in fostering a community and in presenting our discipline to the outside. Fostering community means creating a welcoming environment to all by promoting all forms of intellectual and personal diversity, 
promoting the careers and opportunities of younger scholars, recognizing accomplishments and excellence, and promoting debate and discussion. Presenting the discipline to the outside means encouraging scholarly engagement with the major issues of our time. I believe we can encourage internal debate at the same time as we enhance our profession's ability to engage with the major issues of our time.

\section{Martha Finnemore}

Martha Finnemore is University Professor of Political Science and International Affairs at George Washington University in Washington, DC. Her research focuses on global governance, international organizations, ethics, and social theory. She is the coauthor (with Michael Barnett) of Rules for the World: InternationalOrganizations

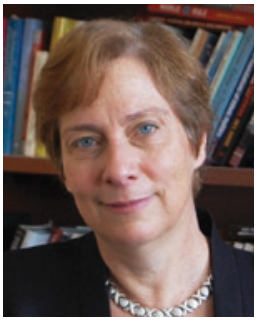
in Global Politics,

which won the International Studies Association's award for Best Book in 2006. She is also author of National Interests in International Society and The Purpose of Intervention, which won the APSA Woodrow Wilson Award as "the best book published on government, politics, or international affairs" in 2004. Her most recent books are Back to Basics: State Power in a Contemporary World (Oxford University Press 2013) and Who Governs the Globe? (Cambridge University Press 2010). Her articles have appeared in International Organization, World Politics, Annual Review of Political Science, Review of International Studies, Review of International Political Economy, Global Governance, Foreign Affairs, and elsewhere. She is a Fellow of the American Academy of Arts and Sciences, has been a visiting research fellow at the Brookings Institution and Stanford University, and has received fellowships or grants from the MacArthur Foundation, the Social Science Research Council, the Smith Richardson Foundation, and the United States Institute of Peace.

Statement of views: APSA must continue to support its diverse members in their varied scholarly activities, but it must also adapt to some new challenges. Work conditions for many members are changing, funding sources for scholarship are changing, and scholarly approaches are shifting in ways that require innovation and attention. In addition to serving our members, I would encourage more public engagement by APSA to bring relevant scholarly work to the attention of citizens, policy makers, and the media in ways that improve public debate on issues of scholarly concern.

\section{David Obey}

Congressman David Obey represented Wisconsin's 7th Congressional District in the House of Representatives for 42 years. He is the longest serving member of Congress in Wisconsin history. Of the over 10,000 men and women who have served in the House in the nation's history, only 21 have

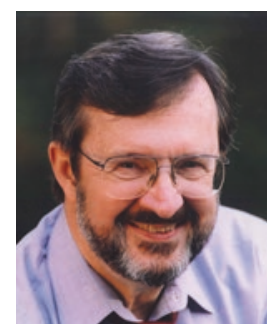
served longer.

When he was first elected on April 1,1969, he was the youngest member of the House in the nation. Before his election to Congress, he served in the Wisconsin State Assembly for $61 / 4$ years, where he served as Deputy Leader. He is a graduate of the University of Wisconsin with undergraduate and MA degrees in political science with a focus on Russian area studies.

In Congress, he served two terms as Chairman of the Joint Economic Committee where he focused committee attention on America's growing income disparity.

For ten years, he chaired the Foreign Operations Appropriations Subcommittee dealing with issues ranging from the Contra War in Nicaragua to the search for Middle East peace and the collapse of the Soviet Union and the Iron Curtain.

From 1995 until his retirement in 2011, he served as the lead Democrat on the House Appropriations Committee including three terms as Chairman. From 1995 to 2011 he also served as the lead Democrat on the Labor, Health, Education, and Social Services Appropriations Subcommittee including two terms as Chairman. He has been at the center of almost every major budget priority debate for over 20 years.

Throughout his career he has been a leader of progressive forces on issues including worker rights, education, health care, medical research, environmental protection, and international relations. He has also been a key leader in Congressional reform efforts and chaired the committee that wrote a new code of ethics for the House in 1977.

He played a leadership role in the passage of the American Economic Recovery Act after the economic collapse of 2008.
He also presided over the House when it passed the landmark Health Insurance Reform Act.

Since retiring from Congress, he has served as a senior fellow at the Wisconsin Institute for Public Policy and Service (WIPPS), headquartered at the University of Wisconsin, Marathon County. WIPPS is a non-profit institute that addresses local, state, and national issues by linking public scholarship, civic outreach, and student service to enhance communities. It is designed to be responsive and collaborative, bringing non-partisan approaches, tools, and resources to help state and local governments, businesses, non-profit organizations, and citizens address and solve real problems.

\section{TREASURER}

\section{Teaku Lee}

Taeku Lee is professor of political science and law at University of California, Berkeley. His research interests are in racial and ethnic politics, opinion polling and survey

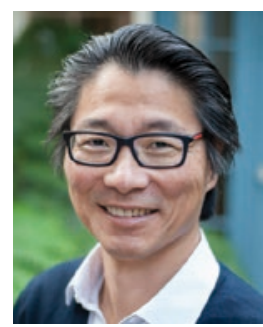
research, and political participation and social movements. He has (co)written or (co)edited Mobilizing Public Opinion (2002); Transforming Politics, Transforming America (2006), Why Americans Don't Join the Party (2011), Accountability through Public Opinion (2011), and Asian American Political Participation (2011).

Lee is also Non-Resident Senior Fellow at the Brookings Institution and managing director of Asian American Decisions. He currently serves on the board of the ANES and the Board of the GSS. He has previously served on the APSA Council, as department chair at Berkeley, and MPSA conference cochair. Prior to Berkeley, Lee was assistant professor at Harvard and Robert Wood Johnson Scholar at Yale. He was born in South Korea, grew up in rural Malaysia, lower Manhattan, and suburban Detroit, and is a proud graduate of $\mathrm{K}-12$ public schools, the University of Michigan (AB), Harvard University (MPP), and the University of Chicago (PhD).

Statement of views: Political science today, as a discipline and as a profession, faces truly pressing challenges. Public investments in higher education and social science research are diminishing and increasingly vulnerable to partisan politics. Tenure track jobs are contracting and inequality within our ranks is intensifying at an alarming rate. 
The diversity of the students we teach far outpaces the membership of our association. The association continues to aspire to greater representation and relevance to non-PhD granting institutions and non-US institutions, and more.

Given these challenges, APSA's central mission as a professional association that safeguards the interests of its membership and advances the disciplinary ends of teaching, mentoring, research, and outreach has never been more critical. APSA has a pivotal role to play in promoting research and teaching that trains our future colleagues, engages real-world problems, contributes to policy making, and illuminates political discourse. It also has a special duty to advocate for a plural vision of our disciplinary good, premised on the spirited promotion of a diversity of methodologies, theoretical standpoints, and social groups representing political science. If fortunate enough to be elected, I would vigorously champion the pursuit of these aims.

\section{SECRETARY}

\section{Suzanne Mettler}

Suzanne Mettler is the Clinton Rossiter Professor of American Institutions in the government department at Cornell University. Her research and teaching interests include public policy, American political development, political behavior and civic engagement, and inequality.

Mettler is the author of four books, including Degrees of Inequality: How Higher Education Politics Sabotaged the American Dream; The Submerged State: How Invisible Government Programs Undermine American Democracy; Dividing Citizens: Gender and Federalism In New Deal Public Policy, which was awarded the Kammerer Award for the best

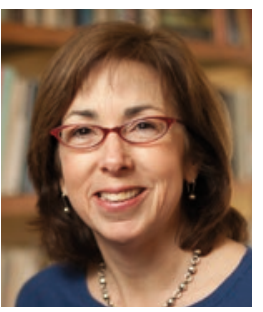
book on US national policy and the Martha Derthick Award for a book that has made an enduring contribution to the study of federalism; and Soldiers to Citizens: The G.I. Bill and the Making of the Greatest Generation, which was also awarded the Kammerer Award as well as the J. David Greenstone prize of the APSA Politics and History section. Mettler has published articles in the American Political Science Review, Perspectives on Politics, British Journal of Political Science, Studies in American Political Development, Journal of Health Policy, Politics, Law, and other scholarly journals and edited volumes. She has coedited two books, The Oxford Handbook on American Political Development and Remaking America. In addition, she has written op-eds for the New York Times and LA Times and essays for The Washington Monthly and Salon.

Mettler's research has been supported by the Russell Sage Foundation, Spencer Foundation, and Robert Wood Johnson Foundation. She serves on the steering committee of the Scholars Strategy Network and is a fellow at the Century Foundation. She is the past president of the APSA Politics and History Section and current president of the Organized Section on Public Policy.

Statement of views: I would seek to represent the diverse needs of our members as they aim to carry out teaching, research, and service in a system of higher education that is under strain from growing demands and diminished resources. I would also like to promote political scientists' greater engagement in public life. In part, this means seeking ways for APSA members to make their research findings more readily available and accessible to journalists, policy makers, and the general public. In addition, the promotion of publicly engaged, problem-driven research can help us to focus on questions of broad and practical significance to society.

\section{COUNCII}

\section{Roxanne L. Euben}

Roxanne L. Euben is the Ralph Emerson and Alice Freeman Palmer Professor of Political Science at Wellesley College. She holds a PhD from Princeton University in politics and Near Eastern studies and a BA in political philosophy from Wesleyan University. Her publications include Princeton Readings in Islamist Thought: Texts and Contexts fromal-Banna to Bin

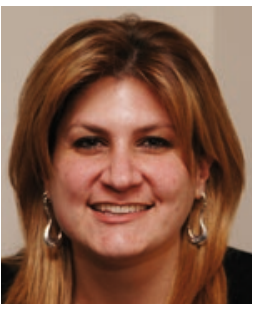
Laden (Princeton), with Muhammad Qasim Zaman, Journeys to the Other Shore: Muslim and Western Travelers in Search of Knowledge (Princeton), and Enemy in the Mirror: Islamic Fundamentalism and the Limits of Modern Rationalism (Princeton). Her work has also been published in Perspectives on Politics, Political Theory, The Review of Politics, The Journal of Politics International Studies Review, Common Knowledge, Current History, Theory and Event, and Political Psychology.

She is now serving as a member of the APSA Committee on Professional Ethics,
Rights, and Freedoms and served as Secretary to the APSA Council in 2009-2010. Her past service to the APSA has also included chairing the Leo Strauss Award Committee as well as serving on the Foundations of Political Theory First Book Award Committee and the Foundations of Political Theory Council. She is currently on the editorial boards of the APSR, Polity, The Journal of Intercultural Studies, Encounters: An International Journal for the Study of Culture and Society, and on the executive editorial board of Political Theory. She has previously served on the editorial boards of The Journal of Politics (2004-2007) and The International Studies Review (1999-2003).

Euben's research has been supported by the National Endowment for the Humanities, the Radcliffe Institute for Advanced Study, the American Council of Learned Societies, and the Mellon Foundation, and her research was recognized with the Frank L. Wilson Best APSA Paper Award. She has also won two teaching awards, the Pinanski Teaching Prize at Wellesley College and the Excellence in Teaching Award at the University of South Carolina. Her current research is on humiliation and gender.

Statement of views: I would be honored to serve on the APSA Council. If elected, I would bring to the Council a long-standing commitment to

- interdisciplinarity in the study of politics;

- methodological pluralism in political inquiry;

- the internationalization of political science, substantively and professionally;

- analyzing and addressing structural as well as nonstructural barriers to diversification of the profession;

- attending to the particular challenges faced by part-time and non-tenure track faculty; and

- programs designed to support first-rate research by faculty at teaching-intensive and/ or underfunded public institutions.

\section{Amaney A. Jamal}

AmaneyA. Jamal is the Edward S. Sanford Professor of Politics at Princeton University and director of the Mamdouha S. Bobst Center for Peace and Justice. Jamal also directs the Workshop on Arab Political Development. She currently is president

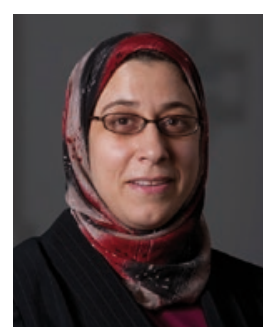


of the Association of Middle East Women's Studies (AMEWS). The focus of her current research is democratization and the politics of civic engagement in the Arab world. Her interests also include the study of Muslim and Arab Americans and the pathways that structure their patterns of civic engagement in the US. Jamal's books include Barriers to Democracy (winner 2008 APSA Best Book Award in comparative democratization), which explores the role of civic associations in promoting democratic effects in the Arab world; Race and Arab Americans Before and After 9/11: From Invisible Citizens to Visible Subjects (coauthor, 2007); and Citizenship and Crisis: Arab Detroit after 9/11 (coauthor, 2009). Her most recent book, OfEmpires and Citizens, was published by Princeton University Press, fall 2012. In addition to her role as director of Princeton's Workshop on Arab Political Development, Jamal is coprincipal investigator of the Arab Barometer Project, winner of the Best Dataset in the Field of Comparative Politics (Lijphart/Przeworski/Verba Dataset Award 2010); co-PI of the Detroit Arab American Study, a sister survey to the Detroit Area Study; and senior advisor on the Pew Research Center projects focusing on Islam in America (2006) and Global Islam (2010). She received her $\mathrm{PhD}$ from University of Michigan in 2003. In 2005, Jamal was named a Carnegie Scholar.

Jamal has served on many APSA-related committees. For example, she currently serves on the APSA Middle East and North Africa (MENA) Task Force; she previously served as the treasurer for the Comparative Democratization Section; and she was the Midwest program cochair in 2012/13. Jamal also serves on the editorial boards of World Politics, Politics and Religion, and the Journal of Middle East Women's Studies.

Statement of views: As a member of the APSA Council, I will work on three important goals. First, I hope to continue to emphasize the importance of methodological pluralism in our field. Second, I will work with APSA to further ongoing diversification efforts. This involves both substantive diversity as well as special attention to the programs that promote the role of women and minorities in our field. And third, I will work with APSA to increase our international profile and think of the best strategies to reach a global audience.

\section{Brett Ashley Leeds}

Brett Ashley Leeds is professor of political science at Rice University. She received her BA from the University of North
Carolina-Chapel Hill and her PhD from Emory University. Her research focuses primarily on the design and effects of international agreements. Much of her work has

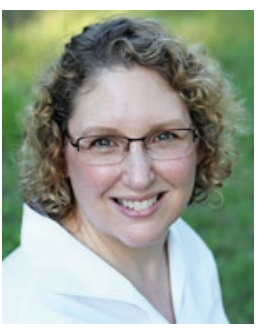
focused on security issues, particularly the politics of military alliances. Her articles have appeared in many journals including American Journal of Political Science, Journal of Politics, InternationalOrganization, and International Studies Quarterly, and her research has been funded by the National Science Foundation.

Leeds was the 2008 recipient of the Karl Deutsch Award from the International Studies Association, which recognizes a scholar under age 40 or within 10 years of defending his or her dissertation who is judged to have made, through a body of publications, the most significant contribution to the study of international relations and peace research. She was the 2014 recipient of the Susan S. Northcutt Award, also from the International Studies Association, which recognizes a person who actively works toward recruiting and advancing women and other minorities in the profession and whose spirit is inclusive, generous, and conscientious.

Leeds has served APSA as president of the Conflict Processes Section 2012-2014, as a member of the 2007 annual meeting program committee, and on three different award committees. She is currently a member of the ad hoc Committee on Governance Reform. She has been active in several other scholarly organizations as well, including the International Studies Association and the Peace Science Society. She has served as associate editor of two journalsInternational Studies Quarterly and the American Journal of Political Science.

Statement of views: If elected, I am committed to working with others as part of the Council to ensure that APSA (1) represents and considers the diverse needs and interests of members; (2) encourages diversity in the profession; (3) provides professional development opportunities to help members gain knowledge and skills related to both research and teaching; (4) continues to develop new ways to encourage interaction among political scientists to improve research and teaching; (5) disseminates political science research to scholarly communities, to policy makers, and to the public; and (6) promotes best practices in research and teaching.

\section{James Mahoney}

James Mahoney is the Gordon Fulcher Professor in Decision-Making and professor of political science and sociology at Northwestern University. He is a comparative-historical researcher with interests in national development, political regimes, Latin American politics, and qualitative methodology.

Mahoney is the author of Colonialism and Postcolonial Development: Spanish America in Comparative Perspective (Cambridge University

Press, 2010), which received five major book awards, and of the earlier prizewinning book, The Legacies of Liberalism: Path Dependence and Political Regimes in Central America

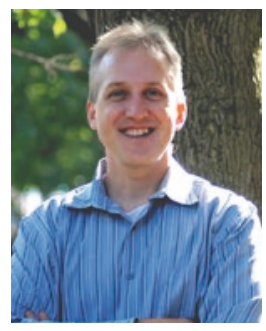

(Johns Hopkins University Press, 2001). $\mathrm{He}$ is also coeditor of Comparative Historical Analysis in the Social Sciences (Cambridge University Press, 2003). Mahoney's article publications have been recognized with several awards, and he has received grants from the National Science Foundation, including a Career Award.

Mahoney has been president or chair of four different Organized Sections of American Political Science Association and the American Sociological Association. He has received two mid-career achievement awards for his work on methodology. He is coeditor of the Strategies for Social Inquiry book series at Cambridge University Press.

Statement of views: I would consider it a privilege to serve on the APSA Council. I am a long-standing advocate of methodological pluralism in the discipline. I am also strongly committed to promoting diversity in the profession. If elected, I would work to ensure that APSA continues to support questiondriven research employing a diverse range of methodologies, including both qualitative and quantitative methodologies. I would also promote APSA's work on mentoring programs for students and junior faculty, especially for women and underrepresented groups in the discipline.

\section{Byron D'Andra Orey}

Byron D’Andra Orey earned a BS degree from Mississippi Valley State University, Masters from the University of Mississippi and the State University of New York at Stony Brook, and a $\mathrm{PhD}$ from the University of New Orleans. He has taught at the 
University of Mississippi and the University of Nebraska, Lincoln, and he currently teaches at Jackson State University, where he is professor and former chair of the department of political science.

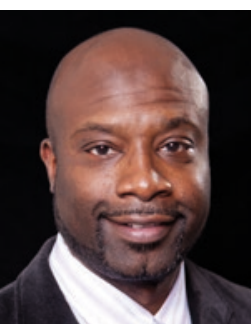
During the 20032004 academic year, he was selected as a Gallup Professor by the Gallup Organization. His research is in the area of race and politics, biopolitics, and legislative behavior. He has published more than 30 scholarly articles and book chapters.

Orey has received multiple university awards, including Teacher and Researcher of the Year. He has also received the Jewel Prestage Teacher and the Rodney Higgins Mentor awards from the National Conference of Black Political Scientists. His research has been supported by the National Science Foundation, TESS, Academic Exchange, and the Palestinian American Research Center, and he has worked with colleagues through a grant from the University of California, Irvine for undergraduates to participate in a summer research program.

Statement of views: My views on the role of political scientists as individuals and political scientists as a social formation expressed through the APSA are shaped by my biography as a son of the American South. Consistent with the philosophy expressed by one of APSA's past presidents, David Easton, I believe that our task is not only to develop an objective understanding of political matters, but to also use our knowledge and societal standing to promote desired social change, particularly in those areas such as race, ethnicity, gender, and politics where widespread inequities remain. To that end, I consider myself a scholar-activist with a special commitment to mentoring young men and women who are interested in becoming political scientists. As someone who is committed to civic engagement, I pride myself in leaving the ebony tower and stepping onto the urban concrete. As a member of the APSA Council, I would work to help forge alliances among APSA, major research intensive universities, and historically Black colleges and universities. In that regard, I would continue the tradition established by professors Samuel DuBois Cook, Jewel Prestage, Mack Jones, Hanes Walton, and others. Moreover, given APSA's commitment to diversity, I would work with other Council members to find a way to aid in creating a continuous spotlight on the report of the Task Force on Political Science in the 21st Century. Currently, there seems to be no incentive for departments to improve their efforts in addressing diversity as outlined in the report. On a related issue, I would work with other Council members to create a database of scholars who study race, ethnicity, gender, and politics. Such a database could be used in a variety of conducive ways, one being a resource for editors of journals who are in search of experts who study race, ethnicity, and politics.

\section{Bo Rothstein}

Bo Rothstein holds the August Röhss Chair in Political Science at University of Gothenburg in Sweden, where he is cofounder and head of the Quality of Government (QoG) Institute, which was started in 2004. Rothstein took his $\mathrm{PhD}$ at Lund University in 1986 and served as assistant/associate professor at the department of government at Uppsala

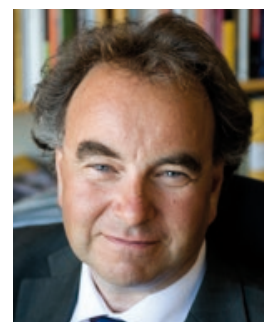
University 1986-1995. He has been a visiting scholar at the Russell Sage Foundation, Collegium Budapest for Advanced Study, Harvard University, University of Washington-Seattle, Cornell University, Stellenbosch Institute for Advanced Study, the Australian National University, and Stanford University. He has served as adjunct professor at University of Bergen and University of Aalborg. His most recent books are The Quality of Government:Corruption, Inequality and Social Trust in International Perspective (University of Chicago Press 2011, also published in Chinese in 2012 by Xinhua Publishers) and the coedited volume Good Government: The Relevance of Political Science (Edward Elgar 2012). Among his other books in English are Just Institutions Matter: The Moral and Political Logic of the Universal Welfare State and Social Traps and the Problem of Trust (both published by Cambridge University Press). He has published in journals such as World Politics, World Development, Comparative Politics, Governance, Comparative Political Studies, and Politics \& Society. Since 2012 he has been a member of the Royal Swedish Academy of Sciences. In 2003, he was awarded a Leading Scholars Grant by the Swedish Science Council, and in 2013 he received an Advanced Research Grant from the European Research Council. He is a regular contributor to the public debate in Sweden and (to a minor extent) internationally on issues such as social justice, social policy, anticorruption, and human well-being.

Statement of views: I have long since been engaged in discussions about the ethics, professional standards, and relevance of the political science discipline. Among my publications in this field are "Is Political Science Producing Technically Competent Barbarians?" in European Political Science (2005) and "Human Well-being and the Unsung Relevance of Political Science," Gerry Stoker et. al. (eds.) in The Relevance of Political Science (Palgrave 2015). If elected, I would seek to (1) address the issues about the relevance and ethics of political science teaching and research; (2) start a discussion about the organization of the Annual Meeting in order to increase the quality of the panels; and (3) promote efforts by the association for increasing collaboration and exchange across the subfields in the discipline.

\section{Cameron G. Thies}

Cameron G. Thies is professor and director of the School of Politics and Global Studies at Arizona State University. He came to ASU in 2013 from the University of Iowa, where hewas previously the Harlan E. McGregor Faculty Fellow and chair of the department of political science. Thies conducts research in the areas of state building in the developing world, interstate and

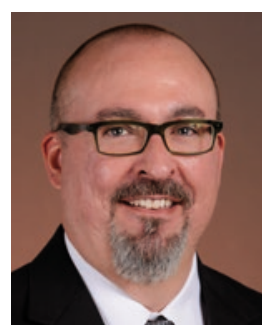
civil conflict, international trade, and international relations theory. He has published in journal outlets such as the American Journal of Political Science, Journal of Politics, British Journal of Political Science, World Politics, International Studies Quarterly, European Journal of International Relations, and Comparative Political Studies, among others. His most recent book is entitled Intra-Industry Trade: Cooperation and Conflict in the Global Political Economy (Stanford University Press, 2015) with Timothy M. Peterson.

Thies has previously served as council member, program chair, and president of the Foreign Policy Section, as well as program chair for International Security, and council member for Political Psychology. He has also been involved with the Teaching and Learning Conference since its inception, including serving multiple times on its Program Committee and moderating numerous workshop tracks through the years. 
Statement of views: I have been a member of the APSA since I was a graduate student. The association provided me with many formative experiences as a student and later a professor in our discipline. As a council member, I would work to increase access to the association through expansion of the annual meeting to accommodate more participants. I would also ensure the continuation of a vibrant Teaching and Learning Conference, which is an intellectual home for many teacher-scholars at liberal arts and community colleges who would not normally attend the annual meeting. I would also like to enhance the international profile of the association to increase our engagement with international associations and draw more international scholars to our events. I would work to continue to develop the association's capacity to advocate on behalf of political scientists in the public sphere, especially when our work is derided as unnecessary and undeserving of public support. Finally, I have a strong commitment to mentoring students and junior faculty and ensuring inclusiveness and diversity in every arena of our professional lives. I would work to continue to develop the association's ability to assist in these important areas of professional development and the development of the profession.

\section{Caroline Tolbert}

Caroline Tolbert is the professor of political science and Collegiate Scholar at the University of Iowa. Her work weaves together a concern with diversity and inequality, elections and representation, and subnational politics and policy. She has contributed to many subfields including digital politics and informatics, voting and elections, electoral systems, public opinion, American state politics, direct democracy, and race and politics.

Tolbert has published more than 50 articles in political science journals and eight books. She is the coauthor of Why Iowa? (2011) on the presidential nominating process. She is also coauthor of Educated by Initiative: The Effects of Direct Democracy on Citizens and Political Organizations in

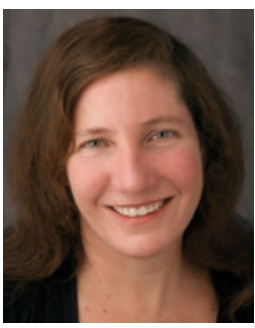
the American States

(2004) and coeditor of Democracy in the States: Experiments in Election Reform (2003) and Citizens as Legislators: Direct Democracy in the United States (1998). She has written three books on the digital politics, including Digital Cities: The Internet and the Geography ofOpportunity (2012), Digital Citizenship (2008), and Virtual Inequality: Beyond the Digital Divide (2003). DigitalCitizenship was ranked as one of the 20 best-selling titles in the social sciences by the American Library Association. She is a coauthor of the American government textbook We the People, with Benjamin Ginsberg, Ted Lowi, and Margaret Weir (W. W. Norton).
Tolbert was named a Collegiate Scholar at the University of Iowa for outstanding research and teaching. She is the recipient of four best paper awards, awards for frequently cited articles, and two book awards. Her research has been funded by the National Science Foundation, Democracy Fund, MacArthur Foundation, HUD, and the Smith Richardson Foundation. She was program chair for the Midwest Political Science Association, president of APSA's State Politics Section (2011-2013), and one of the founders of Visions in Methodology (VIM) conferences to mentor women scholars. She received her PhD from the University of Colorado, Boulder.

Statement of views: As a part of the APSA Council, I aim to create bridges and improve communication among scholars across subfields using different methodological approaches. Rather than subfield silos, I seek a broad education for our students and collaboration between faculty using multiple methods of inquiry. I want to work on student mentoring, education, and professionalization. This includes improving APSA's mentoring program via pairing of mentors and mentees by involving section presidents. I am committed to promoting diversity in the association via awards, mentoring, conferences, and the publication process of APSA's journals. Finally, I seek ways that we can reward research that engages and addresses real-world policy problems. I believe these conversations will help scholars to tackle the many political and policy problems we face in the new century.

\section{Continuing Council Officers and Members}

\section{INCOMING PRESIDENT Jennifer Hochschild}

Jennifer Hochschild is the Henry LaBarre Jayne Professor of Government, professor of African and African American studies, and a former Harvard College Professor at Harvard University. She holds lectureships in the Harvard Kennedy School and Harvard Graduate School of

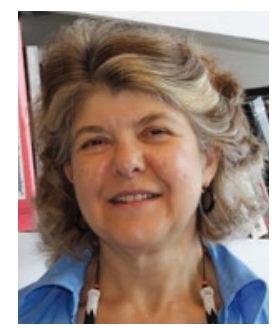

Education. In 2011, she held the John W. Kluge Chair in American Law and Governance at the Library of Congress, and in 2013-14, she was a Fellow at the Straus Institute for the Advanced Study of Law and Justice at New York University Law School.

Hochschild studies and teaches about the intersection of American politics, history, and political philosophy; she focuses especially on race, ethnicity, and immigration. She also studies educational and social welfare policies, the politics and ideology of genomic science, and public opinion and political culture. Most recently, Hochschild coedited Outsiders No More? Models of Immigrant Political Incorporation (Oxford University Press 2013) and coauthored Creating a New RacialOrder: How Immigration, Multiracialism,
Genomics, and the Young Can Remake Race in America (Princeton University Press 2012). Her forthcoming book, also coauthored, is Facts in Politics: What Do Citizens Know and What Difference Does It Make? (University of Oklahoma Press,2014).

Hochschild was founding editor of Perspectives on Politics, and a recent coeditor of the American Political Science Review. She is a Fellow of the American Academy of Arts and Sciences, former cochair of the annual convention and vice-president of the APSA, a former member of the boards of trustees of the Russell Sage Foundation and General Social Survey, and a former member of the DBASSE Advisory Committee of the National 